\title{
Electron Microscopic Observations of Plastids in Seedlings of Pinus densiflora
}

\author{
by Sigenobu KAWAMATU*
}

Received July 21, 1966

\begin{abstract}
Structure and lamellar formation of the plastids were observed in cotyledons of the seedlings of Pinus densiflora grown in the light or in the dark.

In the seedlings grown in the light, chloroplasts have a fully developed lamellar system. Process of lamellar formation is quite similar to that in Angiospermae; the vesicles are lined up together to form lamellae, which develop later into stromaand grana-lamellae, and finally to highly organized lamellar system.

In the plastids of seedlings grown in the dark, lamellar structure was observed, which was formed through the same process as in the light. It was also noted that in this case after the completion of lamellar formation, stroma-lamellae disap. pear, remaining only grana structures. The formation of lamellar system under dark condition was interpreted from the fact that in Pinus chlorophyll was formed in the cotyledon even under the same condition.
\end{abstract}

Many electron microscopic observations on the plastids in etiolated seedlings of Angiospermae ${ }^{1-4)}$, have revealed that in these plastids no lamellar system with grana structures is formed. So far as the author is aware, any electron microscopic observation has not yet been made on the plastids in seedlings of Gymnospermae in the dark. The present paper deals with the structure of plastids in the seedlings of Pinus densiflora grown in the light or in the dark.

\section{Material and Methods}

Seedlings of Pinus densiflora were used as material throughout. A group of seeds sown in a glass vessel was placed on a desk under the diffuse light in a room, and the other group in a glass vessel covered with a glass plate was incubated for 40 days at $28^{\circ}$ in the dark. The seeds were brought into germination in 20 days or a month after sowing, and grew up to the seedlings having 4-6 cotyledons. In order to trace the development of plastid, cotyledons were collected from the seedlings in every week after sowing: slender sections or small pieces of the cotyledon were fixed in $2 \%$ aqueous potassium permanganate for one hour at a room temperature. Preparation of the dark-grown materials was performed under weak green light. After washing with water, the fixed materials were dehydrated in a graded series of ethanol, infiltrated with ethanol-resine monomer $(1: 1, \mathrm{v} / \mathrm{v})$, washed three times with a small amount of the monomer solution, and finally transferred into gelatin capsule. Resine used was a mixture of $n$-butyl methacrylate-methyl methacrylatestylene $(8: 2: 10)$, containing $2 \%$ of benzoyl peroxide as a catalyst. The monomer

\footnotetext{
* Department of Biology, Aichi Kyoiku University, Okazaki, Japan.
} 
was polymerized at $48^{\circ}$ for 2 days. The ultra-thin sections were made using the ultra-microtome JUM-5A, and examined by the electron microscope JEM-7 (Japan Electron Optics Laboratory Co. Ltd.).

\section{Results and Discussion}

\section{Observations on plastids in the seedlings grown in the light.}

No prolamellar body was observed in the plastids in cotyledons of the seedling grown in the light. In these plastids, vesicles are combined together to form lamellae, and the grana stacks also begin to form (Fig. 1). Vesicular swellings also can be seen here and there, chiefly at the end of each lamella. These figures seem to indicate the formation of lamellae by fusion of the vesicles. In a subsequent step more developed lamellar system was observed, in which highly organized grana stacks and stroma lamellae are differentiated (Fig. 2). In the sequel, numerous grana stacks are formed all over the lamellar system (Fig. 3). The process of lamella formation just mentioned is quite similar to the findings in the chloroplast of Angiospermae ${ }^{5-8)}$; the vesicles are lined up together to form lamellae, which develop later into grana- and stroma-lamellae, and finally to highly organized lamellar system.

\section{Observations on plastids in the seedlings grown in the dark.}

In the cotyledon of very young seedlings, two different profiles of prolamellar body are observed in the plastids (Fig. 4). The one shows a regular arrangement of the vesicles, while the other has an irregular arrangement. Vesicles seem to develop from the margin of the prolamellar body and combine with each other to form a lamella. In the plastids of mature cotyledon, grana structure can be seen clearly (Fig. 5 ). In the plastids of more developed cotyledon stroma-lamellae are very poor (Fig. 6). Similar structure of the lamellar system is noted in a young stem of the same material (Fig. 7). In both cases, prolamellar bodies are recognized together with lamellar structure.

In the young cotyledon grown under continuous dark, the plastids have only a few single, large lamellae, but no grana structure (Fig. 8). Many electron dense granules are conspicuous in these plastids. In the mature cotyledon, limiting membrane of the plastid seems to be broken before withering, and the stroma is occupied by disorganized lamella system, prolamellar bodies and electron dense granules (Fig.

9). Some of the lamellae have a structure consisting of several layers.

Now, from the results stated above, it is shown that in the seedlings of Pinus densiflora the process of lamella formation in the light is the same as already reported for Angiospermae ${ }^{5-8)}$, but not in the dark. The etiolated plastids of Angiospermae have only prolamellar bodies and primary lamellae. In the seedlings of Pinus densiflora the lamellar system diffentiated into grana- and stroma-lamellae is formed even under dark condition. This was reasonably expected from the fact that in the Gymnospermae including Pinus the cotyledon and the upper part of hypocotyl of the seedlings become green even when they germinate in the dark.

\section{Acknowledgements}

The author wishes to express his thanks to Dr. H. Iwata of Japan Electron Optics Laboratory Co. Ltd. for giving facilities in preparing the electron micrographs, 
to Prof. M. Hasegawa, Department of Biology, Faculty of Science, Tokyo Metropolitan University, for furnishing the seeds of Pinus densiflora, and to Dr. M. Furuya, Biological Institute, Faculty of Science, Nagoya University, for his help in experiments in the dark room.

\section{References}

1) Eilam, Y., and Klein, S., Jour. Cell Biol. 14: 169 (1962). 2) Jacobson, Ann B., Swift, H., and Bogorad, L., ibid. $17: 557$ (1963). 3) Klein, S., Bryan, G., and Bogorad, L., ibid. $22: 433$ (1964). 4) — 26 : 105 (1961). 6) Murakami, S., Cytologia $27: 140$ (1962). 7) Tōyama, S., and Ueda, R., Sci. Report Kyoiku Daigaku 12: 21 (1965). 8) Wettstein, D. von., Hereditas $43: 303$ (1957).

\section{Explanation of figures}

Fig. 1. Plastid in a young cotyledon grown in the light. Grana stacks, lamellae and vesicular swellings are observed. $\times 30,000$.

Fig. 2. Plastid in a little mature cotyledon in the light. Grana stacks being at the end and also at the middle part of lamellae. $\times 30,000$.

Fig. 3. Plastid in a mature cotyledon in the light. Grana structures and stroma-lamellae developed all over the lamellae. $\times 35,000$.

Fig. 4. Plastids in a very young cotyledon in the dark, prolamellar bodies being distinctly shown. $\times 21,000$.

Fig. 5. Plastid in a mature cotyledon in the dark. Grana structures developed between the lamellae. S: starch grains. $\times 27,700$.

Fig. 6. Plastid in a cotyledon in the dark, showing poor stroma-lamellae. S: starch grain. $\times 25,400$.

Fig. 7. Lamellar system of the plastid in a young stem of the mature seedlings. Only grana stacks being observed, and prolamellar bodies being still present. S: starch grain. $\times 31,000$.

Fig. 8. Plastids in a young cotyledon of the seedling grown under continuous dark. $\times 24,000$.

Fig. 9. Plastids in a mature cotyledon under continuous dark. Limiting membrane of the plastid seems to be broken, and ring structure of several concentric lamellae and prolamellar bodies are noted. $\times 23,700$.

摘要

川松重信：アカマツの芽生えにおけるプラスチッドの電子顕微鏡的観察

明所と暗所で生育したアカマッの芽生えの子葉でプラスチッドの構造とラメラ形成を観察した.

明所で生育した芽生えではラメラ形成は顥花植物のものと全く同じょうである.

暗所で生育した芽生えのプラスチッドは明所の場合と同じ過程でラメラ構造が形成される.ラメラ形成が 完成したのち, ストロマラメラはなくなり，グラナ構造だけとなる，これはアカマッでは暗所に扔いてクロ ロフィルが形成されるので，当然期待されたことである（愛知教育大学生物学教室) 

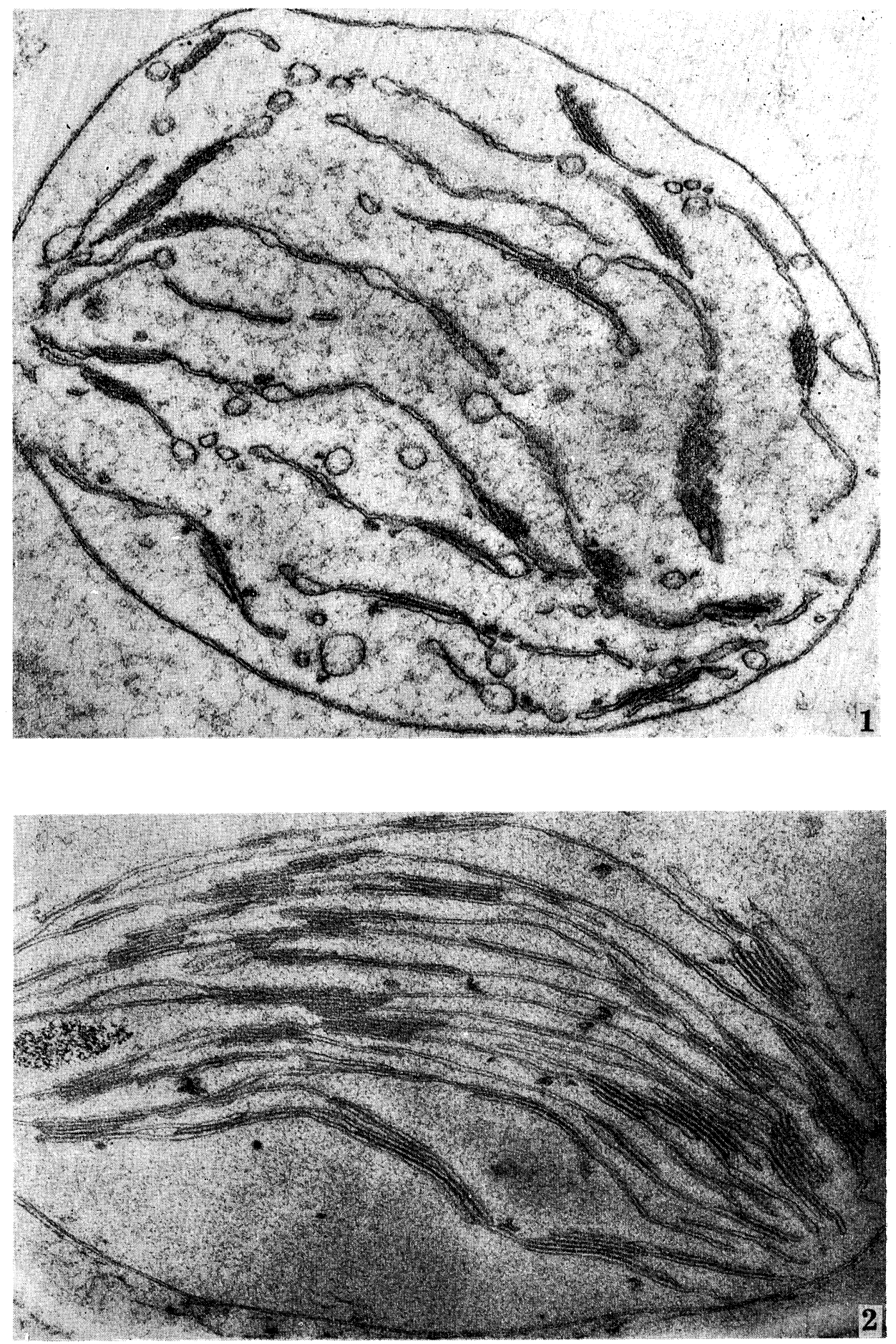


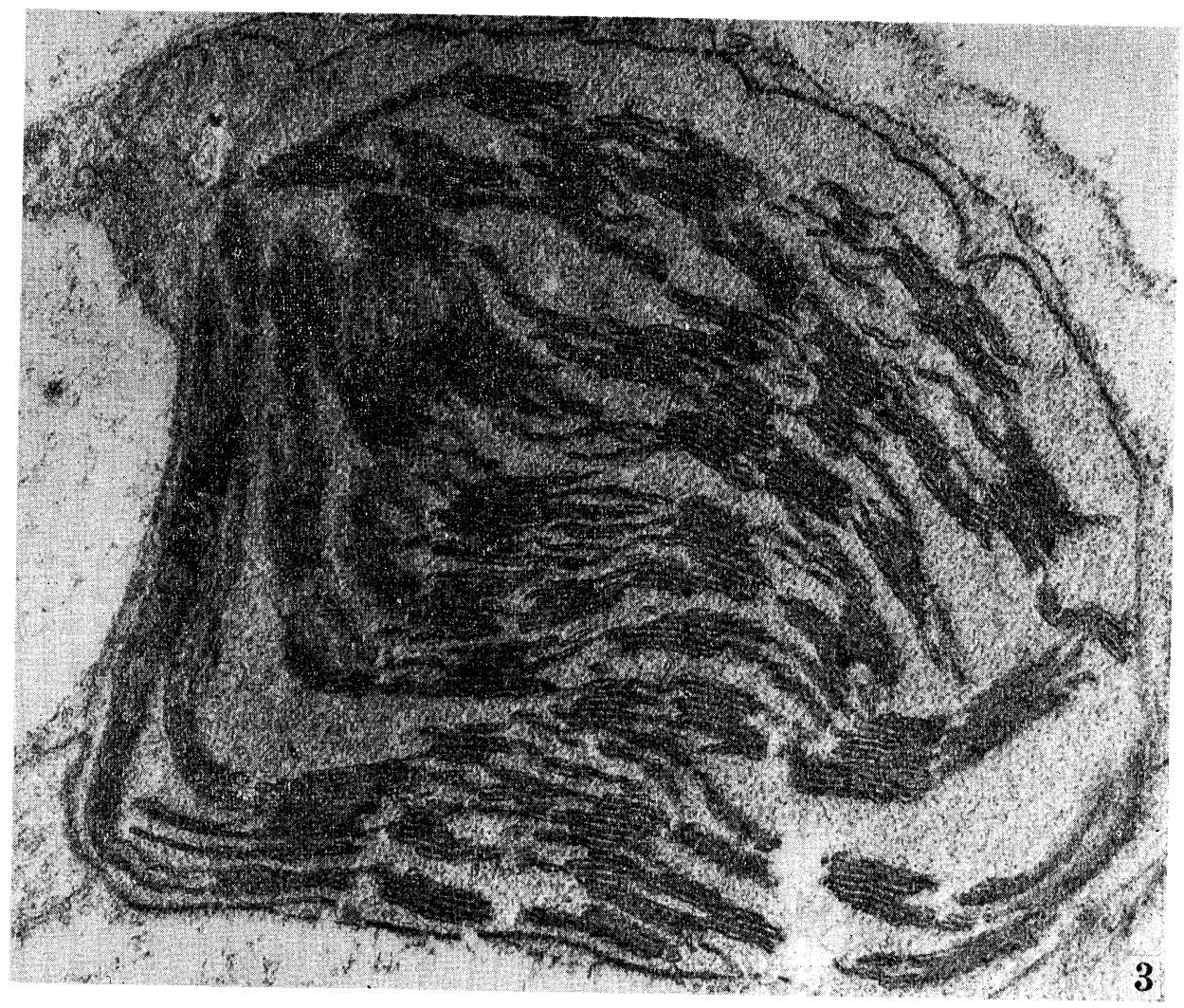



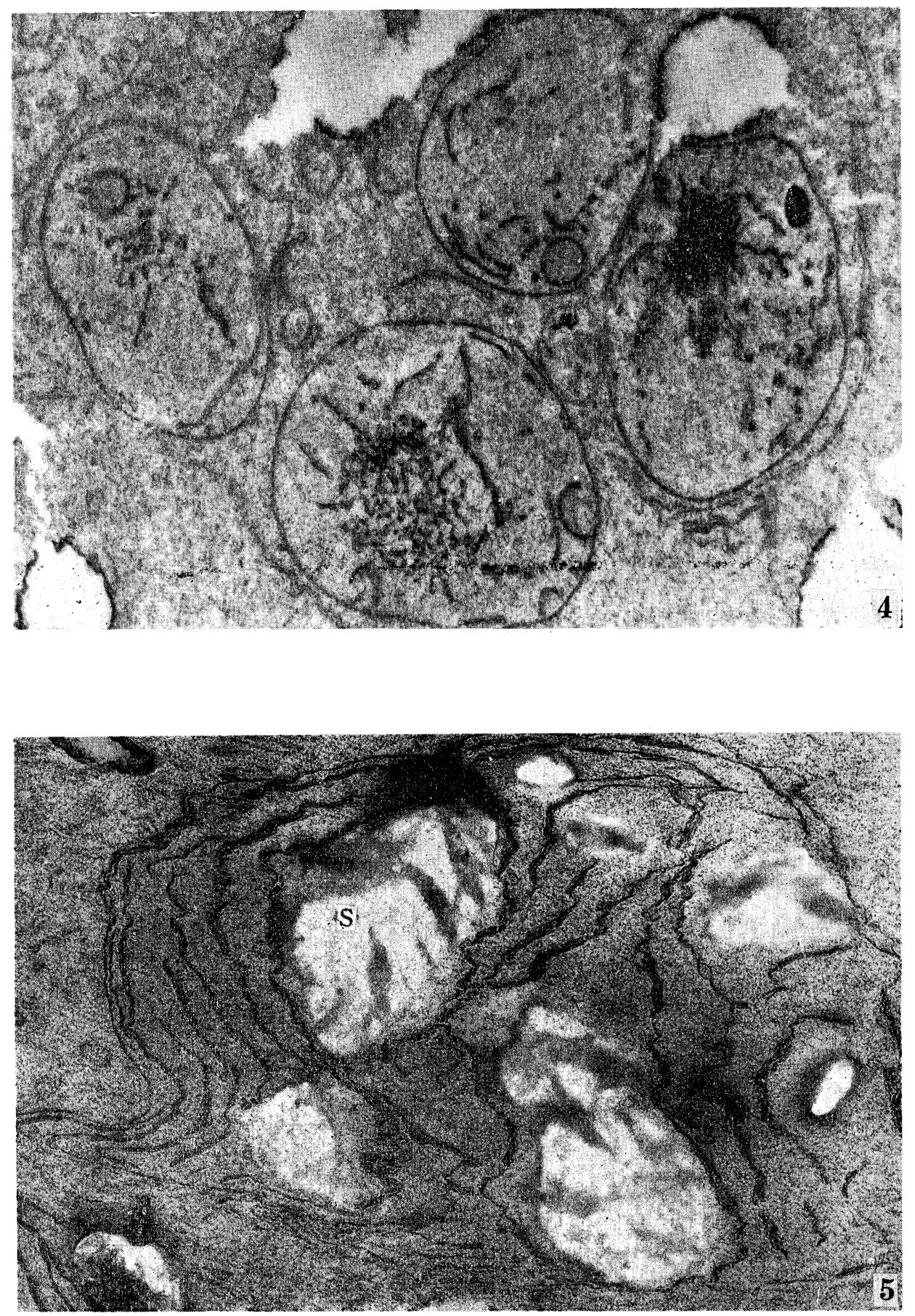

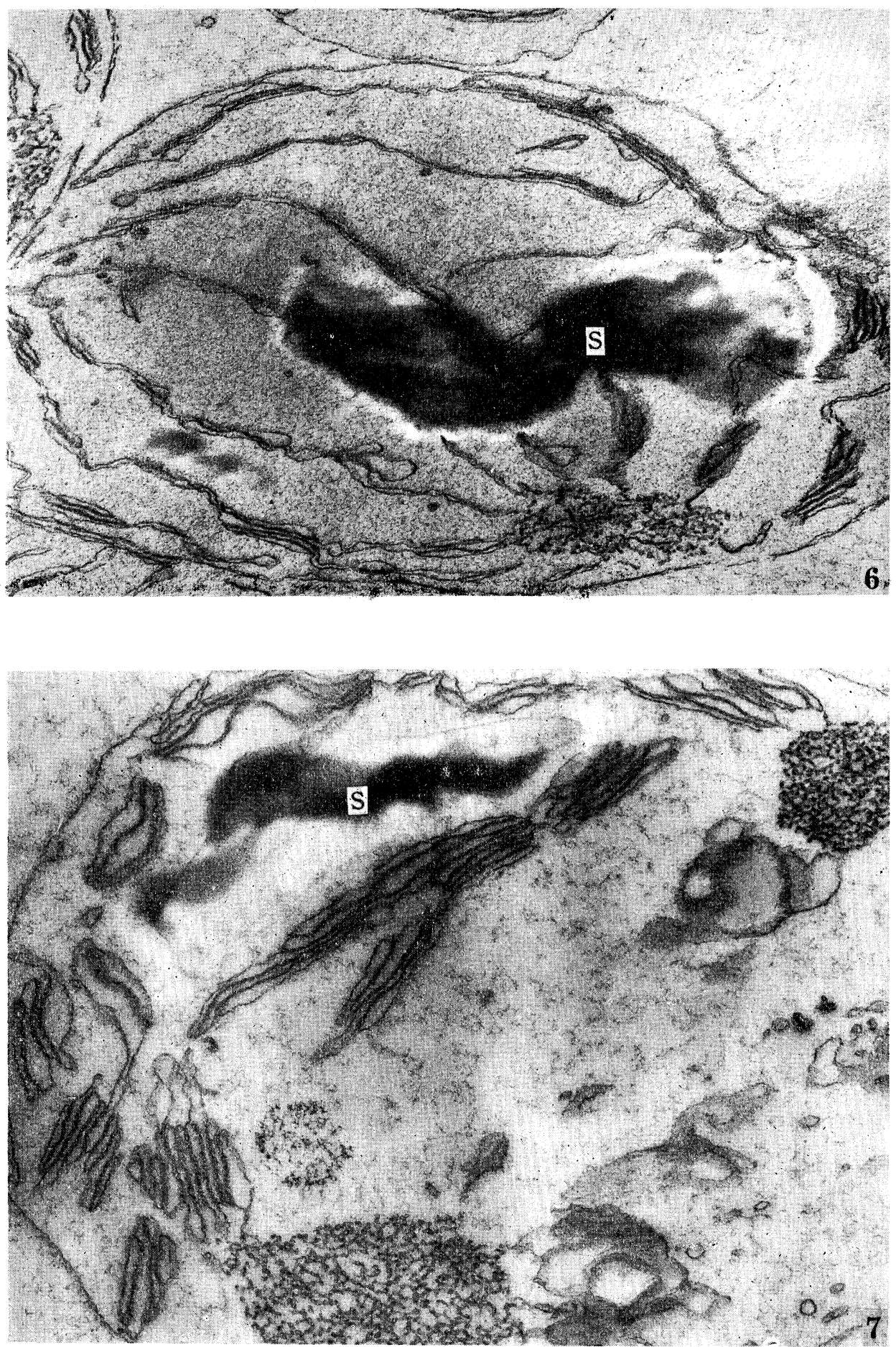

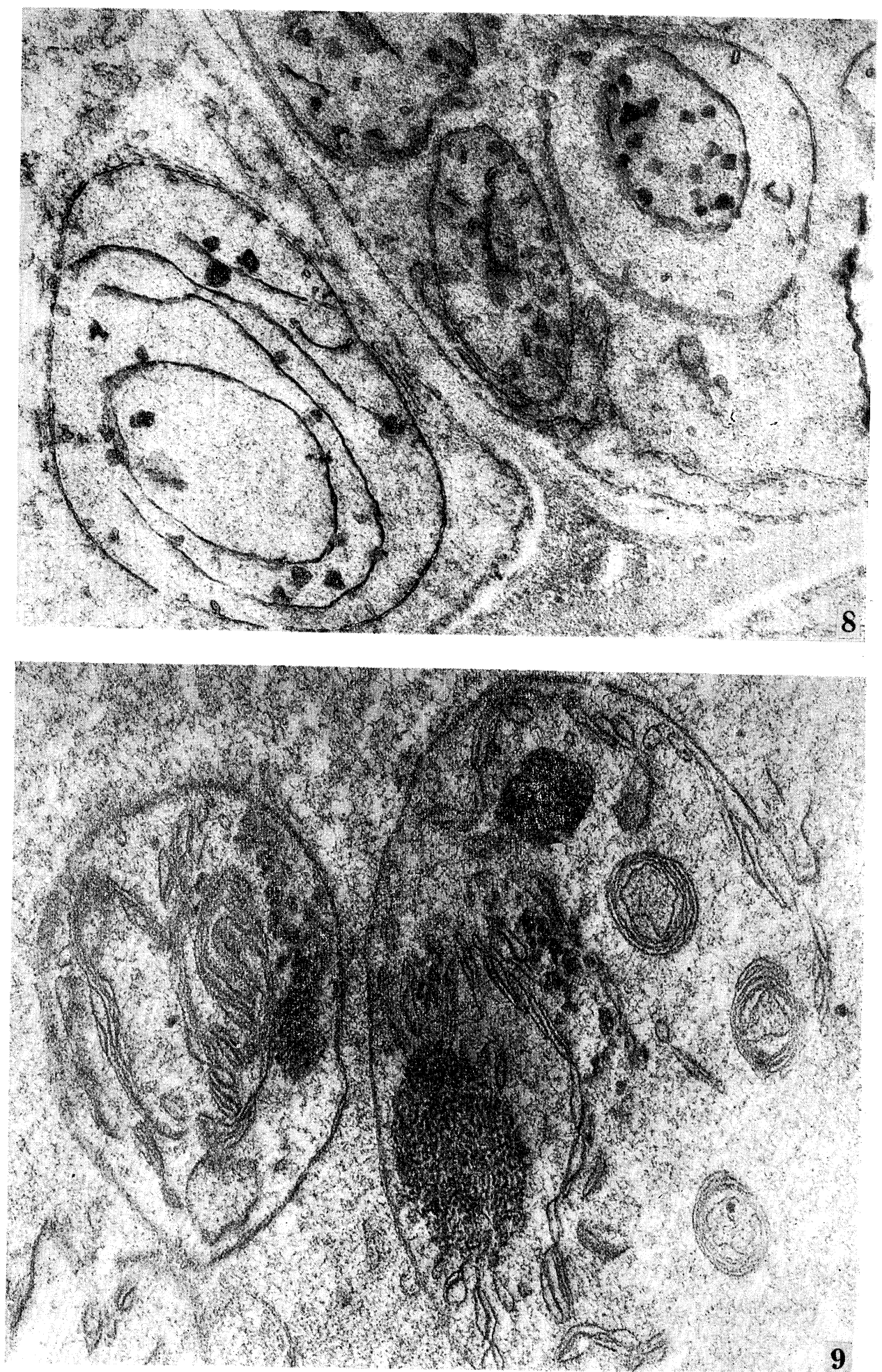